\title{
Peningkatan Pemahaman Tentang Garis Tinggi Pada Segitiga Dengan Pembelajaran Konstruktivisme (Studi Kasus Pada Mahasiswa Dual Mode Konsentrasi IPS, UPI Kampus Serang)
}

\author{
Isrok'atun \\ Program Studi Pendidikan Matematika, Fakultas Pendidikan Matematika dan IImu Pengetahuan Alam, \\ Universitas Pendidikan Indonesia, JI. Dr. Setiabudhi No.229 Bandung, Indonesia
}

Korespondensi; Email: isrokatun@gmail.com

\begin{abstract}
Abstrak
Pengetahuan adalah hasil konstruksi siswa yang mempengaruhi pembelajaran yang lebih bermakna. Terkadang, guru lupa bahwa seorang siswa memiliki pengalaman live-live sebagai konsep awal mereka. Ketika mengemukakan konsep awal mereka, siswa akan lebih mudah menerima pengetahuan material baru, karena siswa akan membangun pengetahuan mereka secara tidak langsung. Konstruktivisme pembelajaran adalah proses belajar mengajar untuk membuat siswa sendiri secara mental aktif untuk membangun pengetahuan mereka, berdasarkan struktur kognitif yang pernah mereka miliki sebelumnya. Dalam hubungan dengan konsep geometri siswa, harus dipertimbangkan bagaimana siswa membangun konsep ini dengan struktur kognitif mereka. Menghafal formulasi matematis bukanlah jaminan bahwa siswa telah menguasai geometri sebenarnya. Misalnya, untuk memahami garis ketinggian di segitiga, bukan proses seketika. Hal ini dapat dipelajari dengan membangun melalui percobaan untuk melibatkan semua tangan siswa pada proses aktivitas. Melalui aktivitas untuk membuat garis ketinggian, mengukur, dan menghitung area segitiga, siswa akan diarahkan pada aktivitas yang menyenangkan, hindari kebosanan, sampai pada kesimpulan bahwa setiap segitiga, ada tiga garis tinggi untuk tiga segitiga di setiap daerah.
\end{abstract}

Kata Kunci: Konstruktivisme; Membangun pengetahuan; Aktivitas tangan; Pemahaman garis tinggi

\begin{abstract}
Knowledge is the student's construction result that affect to the more meaningful learning. Sometimes, teachers forget that a student has self-live experiences as their initial concept. When expressed their initial concept, students will be easier to accept new material knowledge, because students will constructing their knowledge indirectly. The constructivism of learning is a teaching and learning process to make students themselves mentally active to construct their knowledge, based on cognitive structure that they ever had before. In the relationship to the student's geometry concept, it must be considered how the students constructing this concept by their cognitive structure. Memorizing the mathematical formulation is not the guarantee that the students have been mastering to the real geometry. For example, to understand about height line in the triangle, is not an instantaneous process. It can be learned by constructing through an experiment to involving all student hands on activity process. Through the activity to make a height line, measuring, and calculating the triangle area, student will be led on the joyful activity, avoid to the bored, toward the conclusion that every triangle, there are three height lines for the three triangle's bases in each area.
\end{abstract}

Keywords: Constructivism; Construct the knowledge; Hands on activity; Height line Understanding

\section{Pendahuluan}

Sekolah Dasar (SD) merupakan titik tolak yang tepat untuk sebuah usaha pembangunan pendidikan, khususnya bidang studi matematika. SD menjadi basis yang sangat menentukan dalam pembentukan sikap, kecerdasan, dan kepribadian anak didik. Sifat mendasar inilah yang menuntut adanya perhatian khusus dalam pengajaran matematika di SD. Proses belajar mengajar di SD membutuhkan suatu objek dan subjek belajar, selain guru sebagai fasilitator. Subjek belajar disini adalah siswa, 
sedangkan objek belajarnya adalah materi pelajaran matematika, khususnya materi geometri sekolah dasar.

Pengenalan geometri di SD mempunyai beberapa tujuan dasar. Marks (1985, dalam Gunawan, 2004) menyatakan bahwa pengenalan geometri di SD mempunyai tujuan dasar untuk menganalisis lebih jauh dunia tempat hidupnya, serta memberikan sejak dini landasan beberapa konsep-konsep dasar dan peristilahan yang diperlukan untuk studi lebih lanjut. Selain itu, mempelajari geometri juga dapat membangkitkan dan mengembangkan kesenangan intelektual yang sesungguhnya bagi siswa.

SD adalah tempat pertama untuk menanamkan konsep dasar tentang geometri. Dalam hubungannya dengan penguasaan konsep geometri oleh siswa, yang harus diperhatikan adalah bagaimana anak membentuk konsep tersebut dalam struktur kognitifnya. Disini guru mempunyai tugas untuk menciptakan sebuah kondisi belajar yang dapat menunjang terbentuknya konsep-konsep dalam struktur kognitif siswa secara benar. Hafalnya siswa terhadap rumusan konsep belum menjadi jaminan bahwa ia telah belajar geometri dalam arti yang sebenarnya.

Siswa SD pada umumnya berkisar umur 6 tahun sampai 12 tahun. Pada umur tersebut, anak masih kesulitan untuk dapat menerima atau memahami sesuatu yang abstrak, sebagaimana geometri yang bersifat abstrak. Menurut Piaget, (Ruseffendi, 1991) anak umur 7 sampai 12 tahun berada pada tahap operasi konkrit, atau bahkan masih berada pada tahap pre operasi.

Pada tahap pre operasi, anak belum memiliki konsep kekekalan materi (zat). Air dengan volume yang sama, hanya karena di tempatkan pada wadah yang berbeda, mereka akan mengatakan bahwa volume air juga berbeda. Anak juga belum memiliki konsep kekekalan panjang. Seutas tali hanya karena di buat lekak-lekuk, mereka akan mengatakan lebih pendek daripada yang direntangkan, meski panjang keduanya sama. Mereka juga belum memiliki konsep kekekalan luas, serta belum berpikir induktif maupun deduktif, hanya berpikir secara transitif (dari khusus ke khusus). Anak pada tahap operasi konkrit, mulai dapat memahami konsep kekekalan materi (zat), konsep kekekalan panjang, dan juga konsep kekekalan luas, serta mulai dapat memberi alasan secara deduktif dan induktif.

Disinilah peran guru dalam memberikan sebuah sentuhan pembelajaran yang dapat membelajarkan siswa. Sebuah konsep abstrak yang harus dikenalkan kepada anak secara benar, sedemikian hingga anak dapat memahami, baik secara konsep ataupun teoritis. Untuk tujuan ini dibutuhkan penguasaan pendekatan pembelajaran yang sekiranya dapat mengantarkan pemahaman anak SD terhadap geometri oleh guru. Sementara dari sisi gurunya, khususnya guru-guru SD di Kabupaten Serang yang duduk sebagai mahasiswa Dual Modes masih banyak yang belum memahami konsepkonsep geometri secara benar (hasil survei). Jika ada gambar segitiga seperti berikut,

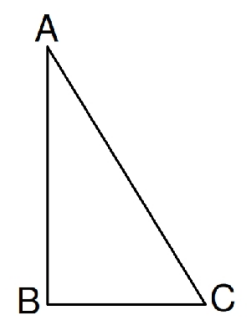

Jika para guru ditanya, dari segitiga $\mathrm{ABC}$ di atas, manakah tinggi dan alasnya, mereka menjawab $\bar{B}$ adalah alas dan $\bar{A}$ sebagai tingginya. Menjawab demikian, karena mereka beralasan bahwa alas segitiga selalu di bawah, sementara tingginya selalu garis yang ke arah atas dari alas tadi. Sehingga mereka berkesimpulan, bahwa dari gambar di atas, maka segitiga $A$ tersebut hanya mempunyai 1 buah alas dan 1 tinggi saja. Dan jika gambar di atas dirubah sedikit, misalnya seperti berikut,

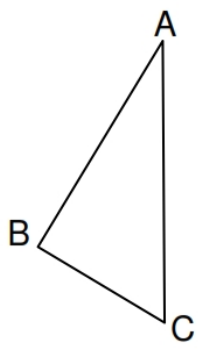


Dari gambar sekarang, manakah alas dan tingginya? Mereka kebingungan, bahkan ada yang menjawab tidak mempunyai alas dan tinggi. Padahal gambar tersebut masih gambar yang sama dengan gambar segitiga sebelumnya, hanya diputar sedikit sehingga terlihat miring.

Oleh karena itu, perlu sekiranya diberikan sebuah pemahaman dengan praktek langsung (hands on activity) kepada para guru SD, guna memberi pemahaman tentang hakikat sebuah garis tinggi pada segitiga sehingga mereka paham akan alas dan tinggi pada segitiga. Pada kesempatan kali ini, akan digambarkan proses pembelajaran geometri kepada mahasiswa Dual Modes melalui pendekatan konstruktivisme, khususnya untuk materi ini.

\section{Rumusan Permasalahan}

Adapun rumusan permasalahan pada studi kasus ini, adalah sebagai berikut.

1. Bagaimana cara menentukan mana yang dinamakan alas dan tinggi pada sebuah segitiga?

2. Bagaimana tanggapan para guru terhadap pembelajaran kontruktivisme ini?

\section{Landasan Teori}

\section{Pembelajaran Konstruktivisme}

Suatu pengetahuan adalah hasil konstruksi siswa sendiri yang menyebabkan belajar akan lebih bermakna. Dengan adanya diskusi dan interaksi dengan siswa lain (tutor sebaya) maka akan mengembangkan strategi dan teknik-teknik baru dalam memecahkan setiap permasalahan.

Teori belajar konstruktivisme memandang bahwa dalam proses belajar mengajar, perolehan pengetahuan diawali dengan terjadinya konflik kognitif (Karli dan Yuliariatiningsih, 2000). Konflik kognitif ini hanya bisa diatasi melalui pengetahuan diri (self- regulation). Pada akhir proses belajar, pengetahuan akan dibangun sendiri oleh anak melalui pengalamannya dari hasil interaksi dengan lingkungannya (Bell, Driver, dan Leach, dalam Karli dan Yuliariatiningsih, 2000: 2-3).

Pada saat seorang pendidik menjelaskan suatu materi pada siswa-siswanya, sebagai pendidik tidak perlu men-drill atau bersusah payah untuk menjejali pengetahuan/materi baru. Terkadang seorang pendidik lupa bahwa seorang anak (siswa) mempunyai pengalaman hidup dalam dirinya sebagai konsep awal siswa. Apabila diungkap konsep awal mereka, maka dengan mudah siswa tersebut dapat menerima pengetahuan/materi baru, karena siswa tersebut secara tidak langsung membangun pengetahuannya sendiri. Pendekatan pembelajaran tersebut dikenal dengan pendekatan konstruktivisme.

Perolehan pengetahuan siswa diawali dengan diadopsinya hal baru sebagai hasil interaksi dengan lingkungannya. Para konstruktivis merekomendasikan supaya para pendidik (guru) menyediakan lingkungan belajar sedemikian hingga siswa dapat mencapai konsep dasar, keterampilan algoritma, proses heuristik dan kebiasaan bekerja sama serta berefleksi. Kemudian hal baru tersebut dibandingkan dengan konsep awal yang telah dimiliki sebelumnya. Jika hal baru tersebut tidak sesuai dengan konsepsi awal siswa, maka akan terjadi konflik kognitif yang mengakibatkan adanya ketidakseimbangan dalam struktur kognitifnya. Melalui proses akomodasi dalam kegiatan pembelajaran, siswa dapat memodifikasi struktur kognitifnya menuju keseimbangan sehingga terjadi asimilasi (Kusdwiratri-Setiono, 1983; Suparno, 1997; Oakley, 2004; Suryadi, 2005).

Berdasarkan uraian tersebut, maka dapat disimpulkan bahwa padangan konstruktivisme dalam pembelajaran adalah suatu proses belajar mengajar sedemikian hingga siswa sendiri aktif secara mental membangun pengetahuannya, yang dilandasi oleh struktur kognitif yang telah dimilikinya. Menurut konstruktivis, belajar matematika adalah proses pemecahan masalah (Suherman, dkk, 2003: 77). Menurut Karli dan Yuliariatiningsih (2000: 4), dalam pembelajaran konstruktivisme, seorang guru harus memperhatikan hal-hal sebagai berikut:

1. Mengakui adanya konsepsi awal yang dimiliki siswa melalui pengalaman sebelumnya

2. Menekankan pada kemampuan minds-on dan hands-on

3. Mengakui bahwa dalam proses pembelajaran terjadi perubahan konseptual

4. Mengakui bahwa pengetahuan tidak dapat diperoleh secara pasif 
5. Mengutamakan terjadinya interaksi sosial.

Guru lebih berperan sebagai fasilitator dan mediator pembelajaran. Penekanan tentang belajar dan mengajar ebih berfokus pada suksesnya siswa mengorganisasi pengalaman mereka, bukan pada ketepatan siswa dalam melakukan replikasi atas apa yang dilakukan guru.

\section{Geometri Sekolah Dasar}

Geometri adalah salah satu materi ajar yang ada pada sekolah dasar. Secara umum materi geometri meliputi titik, garis dan bidang, atau yang lebih dikenal sebagai tiga unsur pangkal dalam geometri. Ketiga unsur tersebut, dapat juga disebut sebagai tiga unsur yang tak didefinisikan. Mempelajari geometri adalah mempelajari sesuatu yang abstrak, seperti halnya titik, garis, dan bidang juga sesuatu yang abstrak.

Materi geometri di SD secara umum berkisar mulai dari apa itu titik, garis, dan bidang sampai pada bangun ruang. Mengenal sifat-sifat yang dimiliki oleh bidang-bidang datar dan bangun ruang, serta penghitungan keliling, luas, serta volume/isi (Sukahar dan Siti-M. Amin, 1995).

Disini guru mempunyai tugas untuk menciptakan sebuah kondisi belajar yang dapat menunjang terbentuknya konsep-konsep dalam struktur kognitif siswa secara benar, dimana kebanyakan siswa berada pada tahap perkembangan mental operasi konkrit (Ruseffendi, 1991). Hafalnya siswa terhadap rumusan konsep belum menjadi jaminan bahwa ia telah belajar geometri dalam arti yang sebenarnya. Oleh karena itu, dibutuhkan suatu pendekatan tertentu yang sekiranya dapat menghantarkan pemahaman siswa SD terhadap geometri yang bersifat abstrak.

\section{Pemahaman Garis Tinggi pada Segitiga melalui Pembelajaran Konstruktivisme}

Pembelajaran konstruktivisme merupakan salah satu alternatif yang dapat diterapkan untuk pembelajaran geometri. Geometri sebagai materi yang dapat dikatakan sebagai materi yang sulit, membutuhkan suatu pendekatan pembelajaran yang dapat lebih memahamkan materi kepada siswa. Kegiatan serupa juga pernah dikaji sebelumnya, yaitu penelitian tentang bagaimana menemukan kembali rumus luas trapesium dengan konstruktivisme sebagai hasil studi kasus pada guru-guru SD di Kota Cilegon-Banten (Isrokatun, 2011). Berikut gambaran dan lembar kerja yang harus dilakukan oleh peserta (mahasiswa Dual Mode konsentrasi IPS) pada penelitian ini.

Kegiatan guna meningkatkan pemahaman garis tinggi pada segitiga bagi para guru SD ini dilakukan pada tanggal 10 Desember 2011 dalam waktu sekitar dua jam. Melibatkan 25 orang mahasiswa yang kesemuanya adalah guru SD. Setiap peserta menyiapkan alat dan bahan yang diperlukan, dan masing-masing menerima sebuah lembar kerja. Pada kegiatan ini, peneliti membuat sebuah lembar kerja guru, yang akan digunakan pada proses pembelajaran. Dari lembar kerja tersebut, jelas tergambar bahwa aktivitas belajar didominasi oleh subyek belajar, dalam hal ini adalah guru. Guru dapat membaca dan melakukan instruksi kegiatan yang ada pada lembar kerja, tentunya dengan arahan dan bimbingan peneliti. Ketika melaksanakan tugas, setiap peserta dapat berkolaborasi dengan teman 1 kelompok, yang terdiri dari 4-5 orang guru. Adapun contoh bentuk lembar kerja, adalah sebagai berikut.

\section{Pemahaman tentang Garis Tinggi dalam Segitiga}

Apa yang Anda pahami tentang garis tinggi? Bagaimana pula tentang pemahaman suatu garis tinggi dalam sebuah segitiga? Garis tinggi adalah suatu garis yang tegak lurus terhadap garis di hadapannya. Untuk memperjelas, silahkan ikuti kegiatan berikut.

Alat dan bahan:

a. Kertas gambar (HVS)

b. Pensil gambar

c. Penggaris

d. Busur derajat atau jangka

Kegiatan:

1. Gambar sebuah segitiga sembarang, kalau memungkinkan gambarlah yang agak besar. Misal, $\Delta A$ 


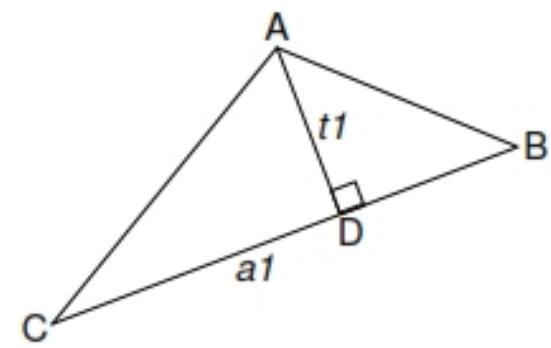

2. Yang sudah kita ketahui, pada $\Delta A$ di atas $\overline{\mathrm{AD}}$ sebagai tinggi dan $\overline{\mathrm{BC}}$ sebagai alas. Sehingga luas $\Delta A=\frac{1}{2}(\overline{\mathrm{AD}} x \overline{\mathrm{BC}})$.

Apakah hanya asa sat ugaris tinggi saja dalam $\Delta A$ ?

3. Untuk menjawab pertanyaan pada no.2 di atas, buatlah perpanjangan garis AC.

Kemudian, tariklah garis dari titik B yang tegak lurus terhadap perpanjangan garis AC tadi, sampai memotong garis tersebut. Dalam membuat garis tegak lurus dapat mempergunakan busur derajat atau pun jangka yang sudah disiapkan.

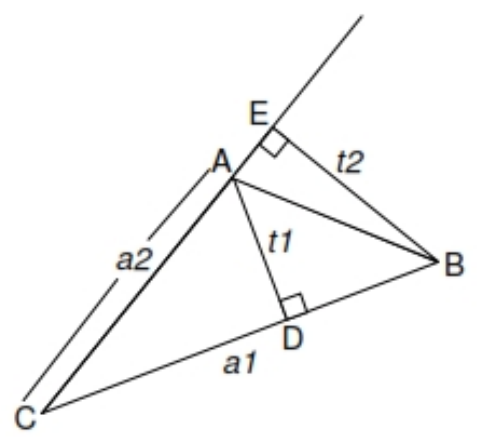

4. Berapakah hasil hitungan $\frac{1}{2}(\overline{\mathrm{AC}} x \overline{\mathrm{BE}})=\frac{1}{2}(\mathrm{a} 2 x \mathrm{t} 2)$ ? Apakah sama dengan $\frac{1}{2}(\overline{\mathrm{AD}} x \overline{\mathrm{BC}})=\frac{1}{2}(\mathrm{a} 1 x \mathrm{t} 1)$ ?

5. Sekarang buatlah perpanjangan garis $A B$. Kemudian, tariklah garis dari titik $C$ yang tegak lurus terhadap perpanjangan garis $A B$ tadi, sampai memotong garis tersebut. Dalam membuat garis tegak lurus dapat mempergunakan busur derajat atau pun jangka yang sudah disiapkan.

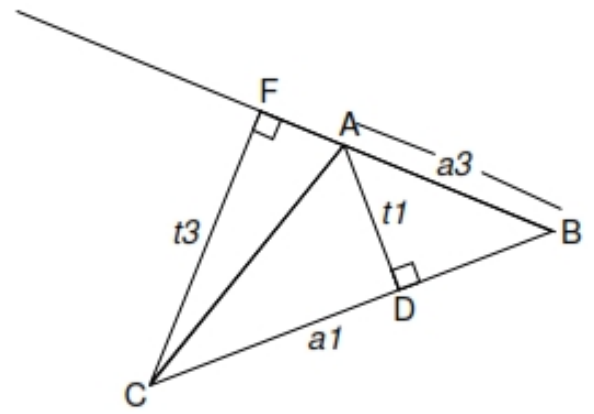

6. Berapakah hasil hitungan $\frac{1}{2}(\overline{\mathrm{CF}} x \overline{\mathrm{AB}})=\frac{1}{2}(\mathrm{a} 3 x \mathrm{t} 3)$ ? Apakah sama dengan $\frac{1}{2}(\overline{\mathrm{AC}} x \overline{\mathrm{BE}})=\frac{1}{2}(\mathrm{a} 2 x \mathrm{t} 2)$ ? Apakah sama dengan $\frac{1}{2}(\overline{\mathrm{AD}} x \overline{\mathrm{BC}})=\frac{1}{2}(\mathrm{a} 1 x \mathrm{t} 1)$ ?

7. Apa yang dapat Anda pahami tentang garis tinggi dalam sebuah segitiga?

8. Dengan demikian, apa kesimpulan Anda?

Sementara itu, mereka juga telah membuat tabel sebelumnya guna mengisikan hasil hitungan sebagaimana perintah yang ada di LKS. Setiap peserta/kelompok menghasilkan hasil hitungan yang berbeda-beda tergantung dari ukuran segitiga yang awalnya mereka buat. Tetapi dari sini dapat dilihat bahwa, meski dihitung dari alas dan tinggi yang berbeda dalam sebuah segitiga, tetap akan menghasilkan jumlah luasan yang sama, yaitu luas segitiga.

Melihat kembali lembar kerja di atas, sebenarnya materi ini adalah materi untuk anak SD, yang bisa saja guru berikan kepada siswanya. Meski awalnya para guru sedikit mengalami kebingungan, 
dengan arahan dari peneliti, proses pembelajaran ini dapat berjalan dengan baik. Hal tersulit yang harus para guru lakukan pada kegiatan ini adalah ketika proses membuat garis tegak lurus dengan menggunakan jangka. Peserta terlihat kaku dan masih kesulitan dalam menggunakan jangka, sehingga beberapa guru ada yang dengan menggunakan penggaris segitiga penyiku. Beberapa dari mereka yang terlihat masih asing dengan alat jangka dan busur derajat, sehingga akan menyulitkan dalam menggunakannya. Peneliti dari awal menyarankan supaya peserta dalam membuat segitiga, yang agak besar dan bentuknya mengikuti seperti bentuk segitiga yang ada pada LKS, yaitu segitiga sembarang. $\mathrm{Hal}$ ini supaya dapat terlihat bahwa, yang tadinya menurut pendapat mereka segitiga tersebut tidak mempunyai alas dan tinggi, bahkan diperoleh 3 buah garis tinggi untuk 3 alas yang bersesuaian. Hal ini dapat dibuktikan bahwa, ternyata dari hasil penghitungan terhadap ketiga alas dan tinggi tersebut, diperoleh hasil yang sama atau mendekati sama (karena faktor bias) tentang luas segitiga tersebut.

\section{Hasil Temuan}

Dari kegiatan studi kasus ini, didapatkan beberapa temuan-temuan penting sebagai berikut:

1. Para mahasiswa, dimana mereka adalah para guru SD di Kabupaten Serang mengungkapkan bahwa kegiatan semacam ini adalah baru pertama mereka temui dan merupakan hal baru

2. Para mahasiswa dapat memahami bahwa garis tinggi adalah suatu garis yang tegak lurus terhadap garis di hadapannya (alas segitiga)

3. Para mahasiswa juga dapat memahami bahwa ternyata pada setiap segitiga hakikatnya mempunyai 3 tinggi untuk 3 alas yang bersesuaian, sehingga jika untuk ketiganya dilakukan penghitungan, maka akan diperoleh hasil luas segitiga yang sama.

4. Mereka menyenangi kegiatan pembelajaran seperti ini, karena mereka dapat lebih fokus dan tidak membosankan. Kegiatan lebih pada kegiatan membuat segitiga sembarang membuat garis tegak lurus, mengukur, dan menghitung luas segitiga dari tiap tinggi dan alas yang berbeda

5. Dapat lebih membuka pemikiran para guru SD akan konsep yang benar dalam segitiga, bahwa yang namanya alas tidak selalu yang ada di bawah an yang namanya tinggi bukanlah yang ke atas

6. Meskipun materi ini sebenarnya adalah materi anak SD, akan tetapi diperoleh fakta bahwa ada beberapa guru yang masih kesulitan mengikuti kegiatan dan instruksi lembar kerja, terutama pada kegiatan membuat garis tegak lurus dari suatu titik terhadap garis dihadapannya, baik menggunakan penggaris segitiga penyiku, apalagi jika menggunakan jangka. Mereka juga terlihat masih kesulitan dalam menggunakan busur derajat guna mengukur besar sudut

7. Para guru mendapatkan pemahaman dari praktek langsung pembelajaran geometri SD sehingga dapat memberikan pemahaman lebih kepada siswa tentang garis tinggi pada segitiga

8. Para guru dapat menyimpulkan, bahwa konsep yang selama ini mereka pahami dan ajarkan ke siswa adalah salah, tentang garis tinggi dan alas pada segitiga kepada siswanya. Bahwa dalam segitiga, akan ada 3 garis tinggi untuk 3 alas yang bersesuaian, dimana setiap garis tinggi selalu tegak lurus terhadap garis dihadapannya (alas).

\section{Kesimpulan}

Berdasar pada hasil-hasil temuan pada penelitian ini, maka dapat disimpulkan bahwa:

1. Pembelajaran konstruktivisme dapat dijadikan sebagai alternatif cara meningkatkan pemahaman tentang garis tinggi pada segitiga. Dalam hal ini yang terpenting adalah bagaimana mendesain proses belajarnya. Guru bukan lagi sebagai pusat pemberi informasi kepada anak, tetapi lebih berperan para fasilitator, motivator, dan pembimbing dalam proses belajar mengajar. Jika memang diperlukan bantuan semacam panduan belajar atau lembar kerja siswa (LKS), maka guru harus membuat desain LKS sedemikian rupa sehingga sesuai dengan kebutuhan pembelajaran konstruktivisme ini. Dan didapat suatu pemahaman bahwa, garis tinggi adalah suatu garis yang tegak lurus terhadap garis di hadapannya (alas segitiga) 
2. Selain mendapatkan pengetahuan konsep geometri yang benar, para peserta kegiatan yang terdiri dari guru SD menanggapi kegiatan pembelajaran konstruktivisme ini secara positif dan antusias. Bahkan mereka merasa, seperti bukan belajar, tetapi hanya kegiatan seperti halnya bermain, akan tetapi pemahaman konsep yang sebagai tujuannya dapat tercapai dengan baik.

\section{Referensi}

[1] Gunawan, A. (2004). Penguasaan Konsep Geometri oleh Murid SD Negeri 38 Kota Bengkulu . Jurnal Penelitian UNIB Vol. X No.1. Bengkulu: UNIB.

[2] Isroka'tun (2011). Menemukan Kembali Rumus Luas Trapesium dengan Konstruktivisme. Jurnal Mimbar Pendidikan Dasar Vol. 2 No. 2, hal. 34-37. Sumedang: UPI Kampus Sumedang.

[3] Karli, H dan Yuliariatiningsih, M.S. (2002). Implementasi KBK 1. Jakarta: Bina Media Informasi.

[4] Kusdwiratri-Setiono (1983). Teori Perkembangan Kognitif. Bandung: Fakultas Psikologi Universitas Padjadjaran.

[5] Oakley, L. (2004). Cognitive Development. London: Routledge.

[6] Ruseffendi, E.T. (1991). Pengantar kepada Membantu Guru Mengembangkan Kompetensinya dalam Pengajaran Matematika untuk Meningkatkan CBSA. Bandung: Tarsito.

[7] Suherman, E., Turmudi, Suryadi, D., Herman, T., Suhendra, Prabawanto, S., Nurjanah, dan Rohayati, A. (2003). Strategi Pembelajaran Matematika Kontemporer. Bandung: UPI.

[8] Sukahar dan Siti-M. Amin. (1995). Matematika 6 Mari Berhitung untuk SD Kelas 6. Jakarta: Departemen Pendidikan dan Kebudayaan.

[9] Suparno, P. (1997). Filsafat Konstruktivisme dalam Pendidikan. Yogyakarta: Kanisius.

[10] Suryadi, D. (2005). Penggunaan Pendekatan Pembelajaran Tidak Langsung serta Pendekatan Gabungan Langsung dan Tidak Langsung dalam Rangka Meningkatkan Kemampuan Berpikir Matematik Tingkat Tinggi Siswa SLTP. Bandung: Disertasi SPs UPI. Tidak diterbitkan. 